\title{
Eliminácia plagiátorstva z projektových prác študentov
}

\author{
Eliminating Plagiarism from Student Project Work
}

\author{
Eva Kaščáková, Henrieta Kožaríková
}

\begin{abstract}
Abstrakt: Projektové vyučovanie je vel'mi populárne už niekol'ko desat'ročí a študenti sa počas štúdia pravidelne stretávajú s rôznymi projektovými úlohami. Napriek tomu, že v čase, ked' začínajú vysokoškolské vzdelávanie majú s projektovou prácou bohaté skúsenosti, mnohým študentom často chýbajú základné akademické návyky a zručnosti, najmä vo vztáahu k akademickej nečestnosti a plagiátorstvu. Príspevok sa pokúša identifikovat' typické porušovanie akademickej etiky v záverečných projektoch kurzov obchodnej angličtiny, ako napríklad neuvedenie autorstva prevzatej myšlienky, úmyselné a neúmyselné plagiátorstvo, nevhodné parafrázovanie, neakceptovatel'né používanie citácií alebo iné nedostatky súvisiace s používaním zdrojov. Autorky sa v príspevku venujú príčinám takéhoto správania a riešeniam, ktoré presahujú využitie sofistikovaných testov originality. Okrem potreby náležitého vzdelávania v správnom citovaní, parafrázovaní a sumarizovaní, poukazujú aj na potrebu prehodnotenia relevantnosti úlohy, ktorá je nevyhnutná pre správne vypracovanie projektu. Dosiahne sa tak nielen originalita výsledkov, ale aj autentickost' práce a rozvoj relevantných zručností pre 21. storočie, ako je kritické myslenie, riešenie problémov, tvorivost', spolupráca, informačná gramotnost', produktivita a zodpovednost'. Nadobudnutie týchto zručností vedie k rozvoju schopnosti autonómneho celoživotného vzdelávania.
\end{abstract}

Klúčové slová: plagiátorstvo, projektová práca, obchodná angličtina, zručnosti 21. storočia, úloha

\begin{abstract}
Project work has been very popular for decades and students regularly encounter various project tasks during their studies. By the time they start university, they have had a lot of experience in project work; however, many students often lack basic academic skills, especially in relation to academic dishonesty and plagiarism. The paper attempts to identify typical violations of ethical academic behaviour in final business English course projects, such as not stating authorship of ideas, intentional and unintentional plagiarism, inappropriate paraphrasing, unacceptable use of citations, or other issues related to the use of resources. The authors discuss the causes of such behaviour and solutions that go beyond the use of sophisticated plagiarism checkers. In addition to the need for appropriate training in correct citation, paraphrasing and summarizing, they also point to the need for reassessing the relevance of the task that is essential for the proper completion of the project task. This will not only achieve the uniqueness of the results, but also the authenticity of the work and the development of relevant skills for the 21st century, such as critical thinking, problem solving, creativity, collaboration, information literacy, productivity and reliability. The acquisition of these skills leads to the development of autonomous lifelong learning.
\end{abstract}

Key words: plagiarism, project work, business English, 21st century skills, task 


\section{Úvod}

Proces výučby cudzích jazykov sa vyvíja už niekol'ko tisícročí. Je to dôsledkom dynamického vývoja jazyka samotného, jazykovedy ako vednej disciplíny, didaktiky, pedagogiky i psychológie. $\mathrm{V}$ priebehu storočí sa pozornost' presúvala zo systému jazyka na spôsob vyučovania až po proces učenia sa. Postupne sa upustilo od používania gramaticko-prekladovej metódy a čoraz viac sa aplikujú metódy vyžadujúce aktivitu učiaceho sa.

Vo výučbe cudzích jazykov je potrebné napíňanie všetkých vzdelávacích cielov, ktoré sú vyjadrené v revidovanej Bloomovej taxonómii (Krathwohl, 2002, s. 213). Od zapamätania a pochopenia nových slov a prvkov jazykového systému, cez ich použitie $\mathrm{v}$ kontexte, analyzovanie jazykových javov $\mathrm{v}$ rámci systému, hodnotenie vhodnosti jazykového prvku v konkrétnom kontexte, až po tvorbu vlastných výstupov (text, blog, wiki-stránky, prezentácie, riešenie problémov, rolové hry, vyjednávanie, debatný príspevok a pod.). Výučba zvyčajne postupuje od nižších kognitívnych procesov (zapamätanie, porozumenie a aplikácia), smerom k vyšším kognitívnym procesom (analýza, hodnotenie a tvorba).

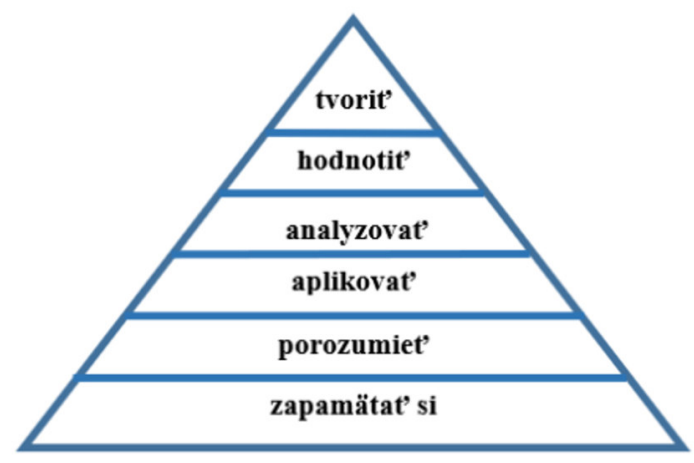

Obr. 1: Revidovaná Bloomova taxonómia vzdelávacích cielov (podl'a Armstrongovej)

V súlade so zásadami konštruktivizmu, ktorý tvrdí, že prácou s informáciami sa počas procesu riešenia úloh poznatky internalizujú, je už niekol'ko desat'ročí populárnou metódou projektové vyučovanie. Projektové vyučovanie sa využíva vo všetkých stupňoch vzdelávania. Hutchinson zastáva názor, že projektová práca podporuje iniciatívu, nezávislost', predstavivost', sebadisciplínu a spoluprácu spolu s rozvojom medzipredmetových zručností, kde sa znalosti získané v iných predmetoch môžu používat' na hodinách anglického jazyka (Hutchinson, 1996). Tento názor je všeobecne akceptovaný a projektové vyučovanie je dlhodobo populárne medzi učitel'mi rôznych predmetov, rovnako aj vo výučbe cudzích jazykov. Pojem 
projektové vyučovanie zahŕňa širokú škálu aktivít, ktoré pozostávajú z vyhl'adávania informácií, ich následného spracovania až k tvorivému výsledku a prezentácii výsledného produktu. Tvorivost’ vlastná aktivitám, ktoré sa nachádzajú na vrchole Bloomovej taxonómie vzdelávacích cielov (Obr. 1), je to, čo učitelia oceňujú a veria, že to prináša výsledky.

Na základe našich skúseností môžeme tvrdit', že hoci zámer zadania tvorivej práce na individuálnych projektoch je sl'ubný, realita dokazuje, že výsledné projekty neprinášajú očakávané výsledky. V prácach študentov sú prítomné znaky plagiátorstva $\mathrm{v}$ rôznom rozsahu a mnohé práce sú neorganizovanými, až náhodnými kompilátmi. Na to, aby študenti splnili úlohu, často iba vyhl'adajú relevantné informácie na internetových stránkach a tie skopírujú do projektu bez uvedenia zdroja, d’alšieho spracovania, či interpretácie. Zaznamenávame nesprávne citovanie a parafrázovanie, kompilovanie bez následnej interpretácie, až po plagizovanie celej práce. Prejavy akademickej nečestnosti nemusia byt' úmyselné, môžu pramenit’ aj z nedostatočnej informovanosti študentov o etickom zaobchádzaní so zdrojmi.

Príspevok prezentuje metódy a výsledky výskumu realizovaného na záverečných prácach z odborného anglického jazyka na Ekonomickej fakulte Technickej univerzity v Košiciach, ktorý pozostával zo štyroch fáz:

1. identifikácia typických prejavov akademickej nečestnosti,

2. analýza pomeru prác so znakmi plagiátorstva a neakceptovatel'nej kompilácie k akceptovatel'ným prácam z pohladu etického zaobchádzania so zdrojmi,

3. analýza ponúkaných tém a kategorizácia typov tém vo vztahu k dostupnosti relevantných zdrojov,

4. analýza popularity jednotlivých typov tém a výskytu znakov neetického zaobchádzania so zdrojmi v súvislosti s typológiou tém.

\section{Príčiny plagiátorstva}

Na základe údajov z literatúry zaoberajúcej sa neetickým narábaním so zdrojmi a skúseností z rozhovorov so študentmi sme identifikovali príčiny, ktoré môžu viest’ k neetickému zaobchádzaniu so zdrojmi pri tvorbe projektových prác.

- Jednou z príčin neetického zaobchádzania so zdrojmi je kultúrna predispozícia - informácie a vedomosti sa v niektorých kultúrach pokladajú za kolektívne. Preto v rámci vzdelávania nie je štandardom ich objavovanie a spracovávanie, ale odovzdávanie, memorovanie a zdiel'anie (Reid, 1993,89; Carroll, 2002; Ryan, 2000).

- Študenti majú nesprávne návyky zo základného a stredoškolského vzdelávania, ktoré môžu byt' dôsledkom popularity projektového vyučovania. Na týchto 
stupňoch vzdelávania však často absentujú informácie a inštrukcie k správnemu využívaniu zdrojov.

- Každodenné správanie na sociálnych sietach tiež ovplyvňuje postoj študentov k priznávaniu autorstva, kedže zdielanie rôznych obsahov bez ohladu na autorstvo je bežnou praxou.

- Študenti nemajú dostatok skúseností s akademickým písaním; princípy a zásady akademickej práce sa nevyučujú.

- Dôvodom používania cudzích formulácií alebo textov je aj strach z chýb, spôsobený neistotou pri používaní cudzieho a/alebo akademického jazyka,

Uvedené dôvody môžu byt' príčinou neúmyselného plagiátorstva. Ďalšie z príčin súvisia skôr s úmyselným neetickým narábaním so zdrojmi:

- Pre plagizovanie sa študenti niekedy rozhodnú pod časovým tlakom, ktorý môže byt' spôsobený zlým časovým manažmentom alebo nedostatočným časovým rámcom.

- Ďalšou príčinou plagiátorstva je snaha nájst' cestu najmenšieho odporu, ale aj ekonomické nakladanie so zdrojmi v zmysle dosiahnutia akceptovatel'ného výsledku pri vynaložení čo najmenšieho úsilia.

- Študenti prípady plagiátorstva a neetického zaobchádzania so zdrojmi nevnímajú ako závažné činy, pretože často nie sú primerane postihované (Council of Writing Program Administrators), dokonca ani pri verejne známych osobách.

- Ak spracovanie témy nie je dostatočnou výzvou, pretože je príliš všeobecná (nie je špecifická) a jej vypracovanie si nevyžaduje riešenie problému, študenti sa dopúštajú plagiátorstva, kedže z povahy témy vyplýva, že je $\mathrm{k}$ dispozícii príliš vela zdrojov, čo vedie $\mathrm{k}$ postoju „všetko už bolo napísané, nemám čo objavit"“.

\section{Spôsoby neetického zaobchádzania so zdrojmi}

Projekty, ktoré študenti pripravujú k záverečnej skúške z odborného anglického jazyka sme v prvej fáze výskumu podrobili analýze, s ciel'om identifikovat' typické prejavy akademickej nečestnosti. Analýza preukázala prítomnost' rôznych typov plagiátorstva, ako je nepriznanie autorstva tvorcovi myšlienky a prisvojovanie si cudzích myšlienok, skopírovanie vety alebo celého odseku bez uvedenia úvodzoviek a zdroja, predkladanie vlastných predchádzajúcich prác, ktoré boli vytvorené v rámci iného predmetu (autoplagiátorstvo), či prevzatie celej práce od iného autora a odovzdanie pod vlastným menom. Ďalšími prejavmi sú neprijatel'né spôsob parafrázovania, $\mathrm{v}$ ktorých študenti nepreštylizovali pôvodný text, neoddelili prevzaté myšlienky od vlastných, prípadne pôvodný text dezinterpretovali, alebo neuviedli príslušný zdroj. Vel'mi častým problémom sa ukázala kompilácia citácií 
a parafráz, v ktorej vlastné vstupy študentov v zmysle interpretácie, hodnotenia a postoja k prevzatému materiálu absentujú.

Okrem nami identifikovanými spôsobmi neetického zaobchádzania so zdrojmi existujú aj d’alšie prejavy akademickej nečestnosti. Napríklad, ak je stanovená podmienka použitia určitého počtu zdrojov a študenti reálne požadovaný počet zdrojov nepoužili, dopúštajú sa fabulovania - v zozname použitej literatúry uvádzajú aj bibliografické odkazy, ktoré nepoužili. V prípade zadaní vyžadujúcich prieskum je možné falšovanie dát - ich prispôsobenie želanému výsledku, prípadne fabulovanie, ak sa prieskum vôbec nerealizoval. Asi najtažšie identifikovatel'ným porušením akademickej etiky je práca na objednávku, kde je študent len zadávatelom, ale prácu napísal niekto iný.

V druhej fáze bolo cielom nášho výskumu zistit', do akej miery sa v projektových prácach študentov vyskytujú znaky plagiátorstva, či inej akademickej nečestnosti. Analýze bolo podrobených 257 projektových prác študentov, ktoré boli súčastou záverečnej skúšky z odborného anglického jazyka (Obr. 2). Analýza spočívala v detailom čítaní projektových prác, kontrole bibliografických odkazov a preverovaní „podozrivých“ častí textu pomocou vol’ne dostupných softvérových nástrojov na kontrolu originality. Potvrdil sa nám predpoklad, že učitel’om l'ahko identifikovatel'né „podozrivé“ časti textu, ktoré sa od bežného jazykového prejavu študenta výrazne líšili použitou na úrovni lexiky, syntaxe a štýlu, boli skutočne prevzaté.

Ukázalo sa, že v najvyššom počte prác (v 137 prácach - 54\%) boli zastúpené nevhodné kompilácie citátov a parafráz, pričom chýbal vlastný vklad autora, interpretácia a hodnotenie prevzatej myšlienky textu. V 105 prácach (41\%) sme zaznamenali prítomnost' rôznych znakov plagiátorstva, ako je kopírovanie celých častí prác, pri parafrázovaní myšlienok neuvádzanie zdroja $\mathrm{v}$ texte, len $\mathrm{v}$ bibliografických údajoch, či odovzdanie identického spracovania témy dvoma rôznymi študentmi. Kritériám, ktoré má spíňat' projektová práca študentov s etickým využívaním zdrojov zodpovedalo 12 z odovzdaných projektov (5\%). Plagiáty a nevhodné kompilácie boli zaznamenané $\mathrm{v}$ rámci celého spektra študentov. Hlbšia analýza potvrdila, že neexistuje priama súvislost' medzi jazykovými schopnost’ami študentov, výberom tém projektov v súvislosti s náročnostou spracovania a výskytom neetického narábania so zdrojmi (Kaščáková, Kožaríková, 2019). Výsledky analýzy nás nútili pátrat' po príčinách neetického správania študentov.

\section{Typológia projektov}

Na základe zistenia typických príčin plagiátorstva bolo naším cielom v čo najväčšej miere odstránit' dôvody neetického správania sa študentov pri projektovej práci. $\mathrm{V}$ tretej fáze výskumu sme sa sústredili na analýzu tém záverečných projektov z hladiska náročnosti spracovania témy, dostupnosti relevantných zdrojov a úsi- 


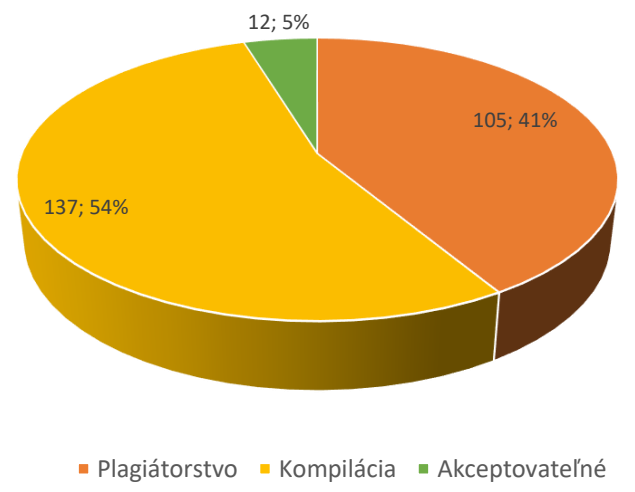

Obr. 2: Identifikovaná prítomnost' znakov akademickej nečestnosti v záverečných prácach

lia, ktoré je potrebné vynaložit' na splnenie úlohy projektovej práce. Ciel' analýzy bol zameraný predovšetkým na špecifikáciu tých vlastností tém projektov, ktoré zabraňujú plagiátorstvu, alebo ho v čo najväčšej miere eliminujú.

V minulosti sme zaznamenávali vysokú mieru plagiátorstva aj v súvislosti $\mathrm{s}$ často nevhodným výberom dobrovolných tém samotnými študentmi. S úmyslom pozorovat', či sa prístup študentov k neetickému narábaniu so zdrojmi zmení, boli študentom stanovené konkrétne témy, ktoré vznikli ako sumár návrhov učitelov Oddelenia anglického jazyka. Tvorbe tém však nepredchádzalo stanovenie prísnych kritérií na formuláciu a charakter projektovej témy.

V rámci záverečnej skúšky z odborného anglického jazyka bolo 257 študentom ponúknutých na výber 50 tém záverečných projektov.

Znaky plagiátorstva a prítomnost' nevhodnej kompilácie, zhromažd'ovania informácií bez vlastného vkladu autora, sme v projektových prácach študentov zaznamenávali aj nad’alej a z toho dôvodu bola analýze podrobená povaha ponúkaných tém. Výskum bol zameraný aj na popularitu tém medzi študentmi, vzájomný vztah medzi výberom a charakterom témy či spracovanie $\mathrm{v}$ súvislosti $\mathrm{s}$ prítomnostou akademickej nečestnosti.

Analýza ukázala rôznorodost' charakteru tém projektových prác. V niektorých prípadoch si spracovanie témy nevyžadovalo vela úsilia a kreatívny prístup autora, kedže bolo možné nájst' mnohé elektronické zdroje týkajúce sa danej problematiky na internetových stránkach, no na výber boli aj témy vyžadujúce vysoko autonómnu a tvorivú prácu študentov.

Na základe charakteru jednotlivých tém študentských projektov boli kategorizované 4 základné typy tém. Náročnost' projektu spojená so špecifickostou témy 
súvisiacej s výskytom počtu relevantných zdrojov stúpala od typu 1 po typ 4 . Jednotlivé typy boli podrobnejšie rozdelené na podtyp a) a podtyp b), pričom podtyp b) v porovnaní s podtypom a) zahŕňa témy odbornejšie a menej známe laickej verejnosti.

Projektové témy typu 1a:

- Ways of leadership in organizations

- Marketing tricks

- Money laundering

- Second-hand stores phenomenon

- Monopolies

- Slovak top entrepreneurs

- An unusual business success story

- E-banking: advantages and disadvantages

- The most famous (or infamous) financial scandals

- The euro and the eurozone. Pros and cons of the euro in Slovakia / in the European Union

- Financial products offered to young people by Slovak banks

Uvedené témy sú všeobecné, venujú sa dobre známej problematike pochopitel'nej aj laickou verejnostou a vel'mi lahko sa $\mathrm{k}$ nim nachádzajú relevantné zdroje na internete. Od študentov sa nevyžaduje riešenie problému, témy nie sú náročné a projektová práca nevyžaduje kreatívny ani analytický prístup. Povaha témy zvyšuje možnost’ plagiátorstva alebo kompilácie jednotlivých častí projektu.

Projektové témy typu 1b:

- Issuing banknotes

- Strategy, philosophy, corporate culture and policy of a profitable company

- Counterfeit products - a widespread problem

- How to build a company

- Start-up financing (How to raise money for a start-up?), business plan for a startup

- Outsourcing, its advantages and disadvantages

- Financial crises and their influence on businesses

- Pros and cons of offshore financial centres

- Issuing banknotes (past and present)

- European central bank and its relation to central banks of EU countries 


\section{- EU Structural Funds}

Témy, ktoré sú odbornejšie a menej známe laickej verejnosti v porovnaní s typom 1a a predpokladá sa, že je k nim dostupných menej zdrojov, ktoré by lahko zodpovedali zadanej téme bez d’alšieho vlastného spracovania.

Projektové témy typu 2a:

- The importance of choosing a good brand name (its meaning + translations)

- Customer service in Slovakia

- Industrial parks in Slovakia

- Slovak tax environment

- Auditing firms in Slovakia

- E-business in Slovakia

- The main Slovak exports and imports

- Present trends in the financial industry (in Slovakia)

Tieto témy sú mierne špecifikované, čo môže plagiátorstvo skomplikovat', ale nie znemožnit'. Neprítomnost' špecifickej úlohy, aj ked' sú tieto témy menej všeobecné, ulahčuje študentom nájst' si zdroje, kopírovat' informácie a upravit' ich tak, aby zodpovedali téme. Mierne zmeny, ako napríklad navrhovanie tém viazaných k určitej lokalite, môžu znížit' možnost' kopírovania, ale nemusia nevyhnutne viest' k vyhýbaniu sa plagiátorstvu.

Projektové témy typu $\mathbf{2 b :}$

- Restructuring of large firms in Slovakia

- Typical features of corporate culture in Slovakia

- The development of the financial industry in Slovakia

- Regulation of the financial sector at present (in Slovakia)

- The growth of the mobile phone business in Slovakia

- The expansion of shopping centres, wholesale and retail chains

- Financing commercial media (TV/radio/newspapers)

Témy sú špecifickejšie ako typ 2a a informácie sú viazané na danú lokalitu, čo redukuje počet dostupných zdrojov v anglickom jazyku.

Projektové témy typu 3a:

- American and European business cultures

- The role of the FED in comparison with the ECB 
- Comparison of two bank products/services

Tieto témy obsahujú úlohu porovnávania, preto už svojou podstatou signalizujú študentom, že je potrebné vykonat' určitú prácu. Úloha založená len na porovnaní však nemusí nevyhnutne vyžadovat' tvorivý prístup, hlboké myslenie alebo riešenie problémov a môže sa riešit' zostavením kompilátu relevantných informácií z rôznych zdrojov bez vlastného vkladu študentov.

Projektové témy typu $\mathbf{3 b :}$

- The importance of reputation (e-companies $v$ brick-and-mortars)

- Investment Banking in the U.S.A. (the UK) and Slovakia

Témy sú špecifickejšie ako typ 3a a vyžadujú porovnávanie a hodnotenie. Pri porovnaní špecifických informácií je menej pravdepodobné, že študenti nájdu hotovú odpoved' na zadanú úlohu, ktorá vyžaduje samostatné porovnávanie a vyhodnotenie informácií, čo redukuje počet dostupných hotových zdrojov v anglickom jazy$\mathrm{ku}$.

Projektové témy typu 4a:

- Ethical policy of a particular company. Why should you do business ethically when unethical behaviour brings more?

- Effective forms of advertising

- China - a threat or opportunity for European businesses? What is behind the absolute advantage of Chinese products?

- My virtual company

- Tax avoidance

- Popularity of debit and credit cards Slovakia (on the basis of a questionnaire). Cash, checks, (credit cards) and electronic money

Tieto témy predstavujú vysoko špecifickú, personalizovanú problémovú úlohu, ktorú je náročnejšie plagizovat', pretože hotová odpoved' je na internetových stránkach nepravdepodobná. Študenti musia informácie o danej téme tažšie hl'adat' a selektovat' relevantné informácie, analyzovat' a dospiet' k určitému záveru, zdôvodnit' svoje závery, vyriešit' problém alebo sa podelit' o osobné skúsenosti. Produktivita, individuálna práca, kritické myslenie a kreativita sú potrebné na dokončenie úlohy a napomáhajú tiež pri predchádzaní plagiátorstvu.

Projektové témy typu $\mathbf{4 b :}$

- How young people manage their assets (on the basis of a questionnaire)

- How to build up a career (on the basis of a questionnaire) 


\section{- An interesting merger/acquisition (case study)}

Podobne ako témy typu 4a, predstavujú vysoko špecifickú, personalizovanú problémovú úlohu, ktorú je t'ažké plagizovat', navyše vyžadujú aj vykonanie dotazníkového prieskumu alebo vypracovanie prípadovej štúdie. Z hladiska klasifikácie vzdelávacích cielov podla Bloomovej taxonómie je na splnenie úlohy potrebné použit' činnosti z vrcholu pyramídy.

\section{Výsledky výskumu}

Zastúpenie tém podla uvedenej typológie v celkovom počte ponúkaných tém (50) je zobrazené na obr. 3. Najvyššie zastúpenie mali témy vyžadujúce najmenšiu tvorivú prácu a počet tém s ich stúpajúcou náročnostou v prvých troch typoch klesal, v štvrtom, najnáročnejšom type sa objavil mierne zvýšený počet tém.

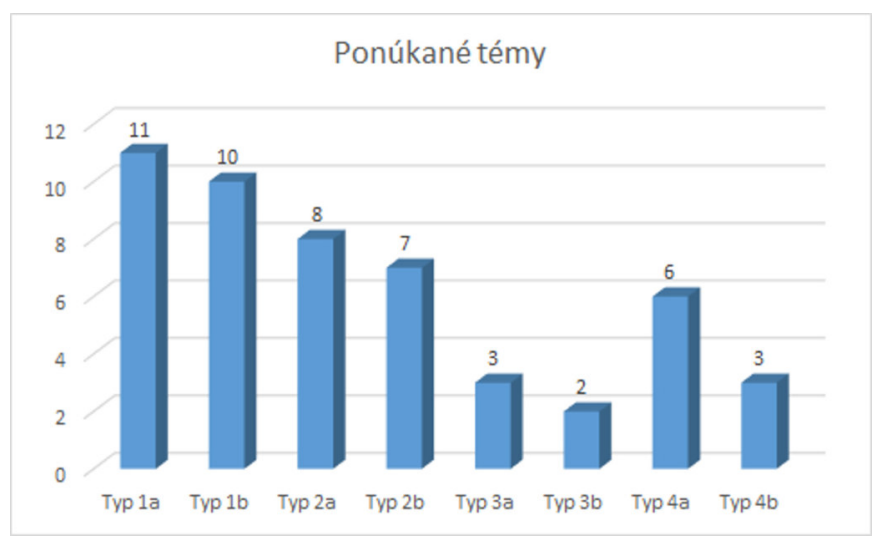

Obr. 3: Zastúpenie ponúkaných tém v rámci jednotlivých typov

Vyčíslenie projektov podla typu vybraných tém prinieslo prekvapivé výsledky (Obr. 4). Popularita tém typu 1a vysoko prevyšuje ostatné témy, kedže až 157 z celkového počtu 257 študentov si vybralo tému spadajúcu do kategórie 1a, čo je $61 \%$. Počty dalších typov postupne klesajú, pričom v každom type b je výrazne nižší počet projektov ako $\mathrm{v}$ type a ( $\mathrm{v}$ typoch $2 \mathrm{~b}$ a $3 \mathrm{~b}$ nulový). Výskum preukázal, že popularita tém s ich stúpajúcou náročnostou klesá.

Obrázok 5 ukazuje súvislost' medzi počtom ponúkaných tém určitého typu a odovzdaných projektov na témy daného typu. Aj ked' ponuka typu 1a je najvyššia (11 z celkového počtu 50 tém), nie je taká vysoká, aby sa popularita typu 1a dala vysvetlit' významne vyššou ponukou tém tohto typu oproti ostatným témam. Tento fenomén vedie $\mathrm{k}$ predpokladu, že motiváciou pre takýto výber tém je najvyššia dostupnost' zdrojov a najnižšia náročnost' témy. Tento predpoklad by však s isto- 


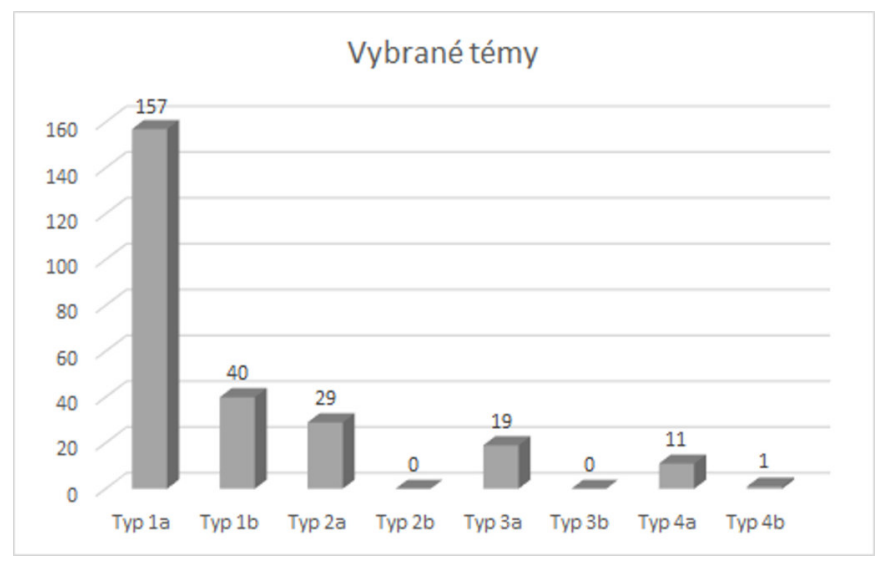

Obr. 4: Počet projektov podl'a vybraných typov tém

tou mohol potvrdit' len d'alší, kvalitatívny výskum prostredníctvom dotazníkov, či riadených rozhovorov so študentmi.

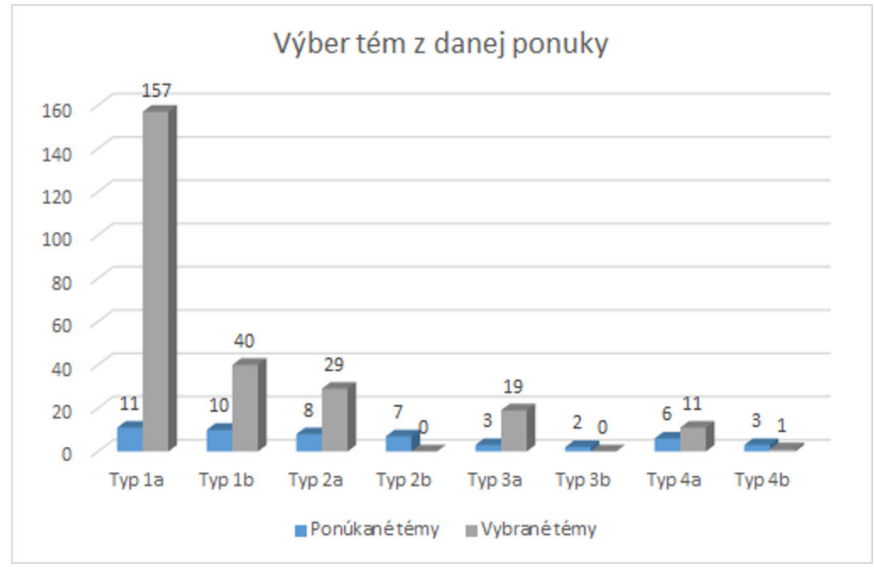

Obr. 5: Počet vybraných tém z danej ponuky príslušných typov

Pri identifikácii neetického narábania so zdrojmi sme vyčíslili počet prác s prítomnými znakmi plagiátorstva a kompilácie (ak boli niekedy prítomné obidva javy, zaradili sme prácu medzi plagiáty) a počet akceptovatel'ných prác z hladiska etického použitia zdrojov podla typológie tém projektov (Obr. 6). V typoch 1-3 vždy prevyšoval počet kompilácií nad plagiátmi. V projektoch na témy typu $4 \mathrm{a}$ a 4b znaky neetického narábania so zdrojmi neboli prítomné vo významnej miere v pomere k vlastnej práci autora. To preukazuje jasnú súvislost' medzi stanovenou 
úlohou a používaním zdrojov pri jej plnení. Súvislost' originality projektov s najvyššou jazykovou úrovňou študentov nebola zjavná, jednoznačné tvrdenie by však mohlo byt' sformulované až na základe d'alšieho výskumu.

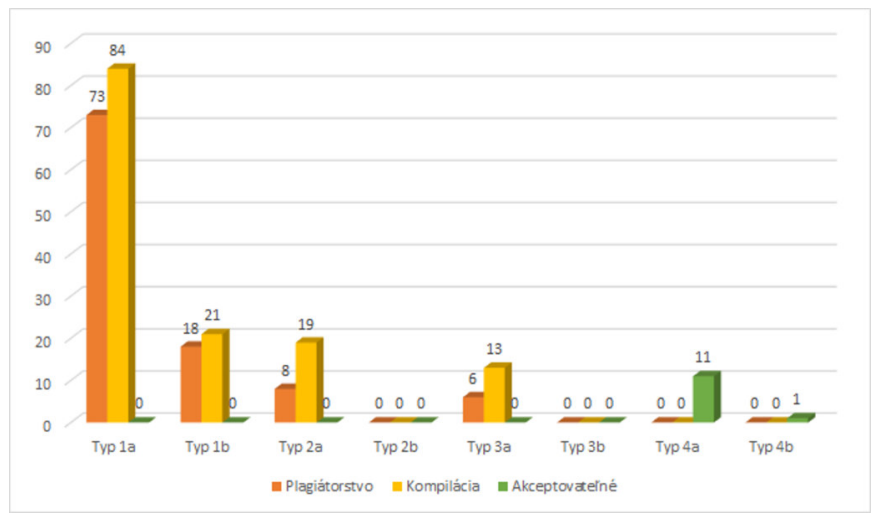

Obr. 6: Výskyt znakov neetického zaobchádzania so zdrojmi v súvislosti s typológiou tém

\section{Návrh riešenia eliminácie plagiátorstva v študentských projektoch}

Samozrejme, je možné preverovat' originalitu každého projektu pomocou softvérových nástrojov. Veríme však, že lepšou cestou je prevencia neetického správania ako jeho penalizácia pri odhalení.

Na základe poznatkov z dostupnej literatúry (Sowell, 2018) môžeme odporúčat' nasledovné kroky na zníženie miery plagiátorstva a iného neetického narábania so zdrojmi:

- zaradit’ základy akademického písania do osnov kurzu,

- zvýšit' povedomie študentov o plagiátorstve (vysvetlit', definovat'),

- poskytovat' náležitú inštruktáž, prax a spätnú väzbu o tom, ako eticky pracovat' so zdrojmi.

Na základe výsledkov výskumu odporúčame predovšetkým implementáciu nasledovných krokov:

- určit' špecifické požiadavky k projektu (napríklad počet a typ použitých zdrojov) a poskytnút' podrobné pokyny,

- zadávat' témy projektu, ktoré sa nedajú l'ahko plagizovat'. 


\section{Stanovenie projektových úloh}

Naše analýzy odhalili nasledujúce charakteristické črty tém projektov, ktoré stáažujú alebo dokonca znemožňujú plagizovanie. Môžu byt' využité ako jedna zo stratégií prevencie plagiátorstva.

- téma nie je všeobecne známa medzi laickou verejnostou,

- téma je špecifická a orientovaná na riešenie úlohy,

- téma je personalizovaná,

- úloha obsahuje riešenie problému,

- zadanie je primerane náročné a vyžaduje tvorivý prístup.

Nasledujúce príklady (Tab. 1) ukazujú zmeny vybraných tém projektu a implementáciu vyššie uvedených vlastností, aby sa účinnejšie zabránilo plagiátorstvu.

Tab. 1: Priklad úpravy tém projektov typu 1-3 na typ 4

\begin{tabular}{|l|l|}
\hline $\begin{array}{l}\text { Pôvodná téma } \\
\text { (Typ 1, Typ 2, Typ 3) }\end{array}$ & $\begin{array}{l}\text { Upravená téma } \\
\text { (Typ 4) }\end{array}$ \\
\hline $\begin{array}{l}\text { Strategy, philosophy, corporate } \\
\text { culture and policy of a profitable } \\
\text { company (typ1) }\end{array}$ & $\begin{array}{l}\text { Company Success - What is behind the success of two particular } \\
\text { profitable companies? (Compare their strategies, philosophies, } \\
\text { corporate cultures and policies and suggest best practices that } \\
\text { you would recommend to a start-up company) }\end{array}$ \\
\hline Slovak tax environment (typ 2) & $\begin{array}{l}\text { Ideal Tax System - An ideal tax system (from the point of view of } \\
\text { a country, companies and individuals) }\end{array}$ \\
\hline $\begin{array}{l}\text { American and European } \\
\text { business cultures (typ3) }\end{array}$ & $\begin{array}{l}\text { Business Cultures - Differences and similarities in business } \\
\text { cultures between Slovakia and a chosen country (suggest two lists } \\
\text { of dos and don'ts for companies that want to start business } \\
\text { in/with Slovakia or the chosen country) }\end{array}$ \\
\hline
\end{tabular}

\section{Ďalšie benefity vyplývajúce z povahy upravenej projektovej úlohy}

Naším primárnym cielom bolo nájst' spôsob ako zredukovat' až úplne eliminovat' plagiátorstvo a neetické zaobchádzanie so zdrojmi v projektovej práci študentov. Zmena typu projektovej úlohy má však aj d’alšie prínosy. Projektová úloha, ktorá svojou povahou vyžaduje rozličné činnosti špecifikované Bloomovou taxonómiou vzdelávacích cielov tiež pokrýva tzv. zručnosti pre 21. storočie. Existujú rôzne zoznamy zručností pre 21. storočie, no ich klúčové zameranie je spoločné: zvýšenie schopnosti človeka prispôsobit' sa zmene. Tieto zručnosti poskytujú adaptabilitu, ktorú l'udia potrebujú na to, aby držali krok s neustále sa vyvíjajúcim pracovným prostredím.

Podla Trillinga a Fadela (2009), prvý súbor zručností pre 21. storočie je klúčom k budúcemu úspechu - tieto zručnosti pomáhajú človeku stat' sa samostatným 
Tab. 2: Zručnosti pre 21. storočie podl'a Fadela (2011)

\begin{tabular}{|l|l|l|}
\hline Učenie sa a inovácie & $\begin{array}{c}\text { Digitálna } \\
\text { gramotnost' }\end{array}$ & Kariéra a život \\
\hline $\begin{array}{l}\text { Kritické myslenie a riešenie } \\
\text { problémov }\end{array}$ & Informačná gramotnost' & Flexibilita a adaptabilita \\
\hline Kreativita a inovácie & Mediálna gramotnost' & Iniciatíva a samostatnost' \\
\hline Komunikácia & IKT gramotnost' & Spoločenská a interkultúrna interakcia \\
\hline Spolupráca & & Produktivita a zodpovednost' za výstup \\
\hline & & Vodcovstvo a zodpovednost' voči iným \\
\hline
\end{tabular}

v procese celoživotného vzdelávania prostredníctvom komunikácie a rozvíjania zručností kritického myslenia.

Druhý súbor zručností pozostáva z toho, čo je potrebné na vyhladanie, vyhodnotenie, použitie a doplnenie informácií, využívajúc rôzne médiá a technológie.

Tretí súbor zručností obsahuje schopnost' prispôsobit' sa zmene, byt' samostatný, nezávislý, schopný komunikovat' s ostatnými v rôznych pracovných tímoch, produkovat' výsledky a prevziat' za ne zodpovednost'. Okrem toho je to aj schopnost' ovplyvňovat' a usmerňovat' ostatných a byt' zodpovedný voči iným a celej komunite.

Ak by sme si za ciel' stanovili rozvíjanie všetkých zručností pre 21. storočie, projektová práca vo dvojiciach alebo skupinách by vd’aka nutnosti spolupráce a komunikácie medzi študentmi navzájom znamenala využívanie kompletného spektra zručností pre 21. storočie.

\section{Záver}

Projektová práca spočíva v hl'adaní informácií, ich spracovaní a prezentácii konečného výstupu. Ak je prítomné plagiátorstvo, študent druhú fázu práce na projekte minimalizuje, až eliminuje (v závislosti od rozsahu plagiátorstva) a informácie len vyhladá a následne prezentuje. Musíme si uvedomit', že druhá fáza procesu práce na projekte, čiže práca s informáciami, je dôležitá súčast' internalizácie vedomostí. Preto by sa táto dôležitá etapa projektovej práce nemala vynechávat'. Výsledky nášho výskumu naznačujú, že zníženie úrovne akademickej nečestnosti je aj v našich rukách. Potrebujeme však zvolit’ skôr proaktívny ako reaktívny prístup. Proaktívny prístup k eliminácii plagiátorstva spočíva vo zvyšovaní povedomia o tejto problematike, vyčlenením času výučby pre teóriu a prax etického zaobchádzania so zdrojmi, ale hlavne zmenou tém projektov a stanovením intelektuálne náročnejšej úlohy, ktorá vyžaduje autonómnu prácu a kreatívny prístup autora. 
Sme presvedčení, že zachovaním dôrazu na druhej fáze projektovej práce, t. j. spracovaniu informácií sa eliminuje plagiátorstvo z projektových prác študentov a zároveň to prispieva k rozvoju klúčových kompetencií pre celoživotné vzdelávanie jednotlivca. Ďalším benefitom je, že takéto nastavenie procesov prinesie väčšiu spokojnost' s našou prácou učitel'ov, pretože je omnoho l'ahšie, intelektuálne zaujímavejšie a eticky prijatel'nejšie zabránit' plagiátorstvu, ako po ňom pátrat'. Nemôžeme úplne vylúčit’ riziko podvádzania prostredníctvom vypracovania projektu na objednávku - ak celú prácu napíše tretia strana v mene študenta; riziko je možné čiastočne znížit' testovaním prezentácie projektu.

\section{Literatúra}

Armstrong, P. Bloom's Taxonomy. Dostupné z https://cft.vanderbilt.edu/guides-sub-pages/blooms -taxonomy/

CARRoll, J. (2002). A handbook for deterring plagiarism in higher education. Oxford, UK: Oxford Centre for Staff and Learning Development.

Council of Writing Program Administrators. (2003). Defining and Avoiding Plagiarism: The WPA Statement on Best Practices. Council of Writing Program Administrators, Dostupné z http:// wpacouncil.org/aws/CWPA/pt/sd/news_article/272555/_PARENT/layout_details/false

Hutchinson, T. (1996). Project Work in Language Learning. The Language Teacher. Dostupné z https:// jalt-publications.org/tlt/articles/2044-project-work-language-learning

KAŠČÁKovÁ, E., \& KožARÍ KovÁ, H. (2019). Do only poor students cheat? Inadequate use of resources in student project work. In IsTRATE, S. L. ET AL. Linguistic Training of Students of Universities of Non-Philological Specialities in the Context of Bologna Process and Recommendations of the Common European Framework of Reference for Languages: Learning, Teaching and Assessment. Odesa: O. S. Popov ONAT.

Krathwohl, D. R. (2002). A Revision of Bloom's Taxonomy: An Overview. Theory into Practice, 41(4), 212-218.

REID, J. M. (1993). Teaching ESL writing. Englewood Cliffs, NJ: Prentice Hall Regents.

RYAN, J. (2000). A guide to teaching international students. Oxford, UK: Oxford Centre for Staff and Learning Development.

Sowell, J. (2018). Beyond the Plagiarism Checker: Helping Nonnative English Speakers (NNESs) Avoid Plagiarism. English Teaching Forum, 56(2). 2-15.

\section{Autorky}

Mgr. Eva Kaščáková, PhD., Katedra jazykov, Technická univerzita v Košiciach,

e-mail: eva.kascakova@tuke.sk

Eva Kaščáková pracuje ako odborná asistentka na Katedre jazykov Technickej univerzity v Košiciach. Vyučuje odborný anglický jazyk v oblasti obchodu, financií, cestovného ruchu, strojárstva, stavebníctva a IKT. Jej profesionálne a výskumné záujmy sa týkajú aplikovanej lingvistiky, didaktiky odborného cudzieho jazyka, vrátane využívania IKT vo výučbe jazykov, hodnotenia a tvorby kurzov.

Mgr. Henrieta Kožaríková, PhD., Katedra jazykov, Technická univerzita v Košiciach, e-mail: henrieta.kozarikova@tuke.sk

Henrieta Kožaríková je odbornou asistentkou na Katedre jazykov na Technickej univerzite v Košiciach. Pôsobí ako učitel'ka odbornej angličtiny (obchodná angličtina, angličtina pre stavebné inžinierstvo, angličtina pre strojné inžinierstvo, angličtina pre počítače) a vyučuje aj slovenský jazyk pre cudzincov. Zaoberá sa aj otázkami didaktiky, aplikovanej lingvistiky, lexikológie a terminológie. 